\title{
The Innovation Development in China in the Context of Globalization
}

\author{
VITALINA BABENKO \\ Department of International E-Commerce and Hotel\&Restaurant Business \\ V.N. Karazin Kharkiv National University \\ Svobody sq., 4, Kharkiv, 61022 \\ UKRAINE \\ OLGA PRAVOTOROVA \\ Department of Administrative and Economic Law and Lawenforcement Activity \\ Kherson State University \\ str. Universztetska, 27, Kherson, 73009 \\ UKRAINE \\ NATALIIA YEFREMOVA \\ Department of Marketing, Entrepreneurship and Production Organization \\ Kharkiv National Agrarian University named of V.V. Dokuchaev \\ p/o "Docuchaevskoe - 2", Kharkiv district, Kharkiv region, 62483 \\ UKRAINE \\ SVITLANA POPOVA \\ Department of Law Enforcement and Police Studies \\ Kharkiv National University of Internal Affairs \\ L. Landau avenue, 27, 61080, Kharkiv \\ UKRAINE \\ IRINA KAZANCHUK \\ Department of Administrative Law and Process \\ Kharkiv National University of Internal Affairs \\ L. Landau ave., 27, Kharkiv, 61080 \\ UKRAINE

\section{VLADISLAV HONCHARENKO} \\ School of International Economic Relations and Travel Business \\ V.N. Karazin Kharkiv National University \\ Svobody sq. 4, Kharkiv, 61022 \\ UKRAINE
}


Abstract: - China's economic development has entered a stage of high quality due to the increasing supply of innovations and the strengthening of the innovation environment. This created the attractiveness of an innovative economic system, conducive to building a modern globalization space. The purpose of the article is to study the current state of China's innovation development; conducting a comparative analysis of individual macroeconomic indicators that characterize the national innovation system between countries. For a detailed examination of the state of development of innovation processes for each country, indicators that contribute to the development of innovation in the country are analyzed. GDP is considered as a sign of innovation and technical condition of the

studied countries; balance of payments; foreign direct investment: $i_{\text {nward }}$ and outward flows and stock, annual. Regression analysis was used as the study method. With its help, on the basis of statistical information for the period 2013-2019, analytical dependencies (growth curves) for each studied indicator were determined. Using the calculated equations of the growth curves, the predicted values of the studied traits for the period 2020-2022 are determined. This is how we see GDP growth, especially for countries such as China and the USA. The forecast showed a positive balance of payments only for Hungary, Russia and Greece, for other countries it is negative, the largest of which is in the USA. Leaders in foreign investment are countries such as China, the USA and Russia, and Ukraine also has a slight but upward trend. Thus, studies show that expanding the scope of market mechanisms and stimulating innovation at the micro level, the Chinese leadership has not lost sight of macroeconomic levers of regulation.

Key-Words: - China's innovation development; Regression analysis; Forecast; Globalization space; Foreign investment; GDP.

Received: November 3, 2019. Revised: May 5, 2020. Accepted: May 20, 2020. Published: May 28, 2020.

\section{Introduction}

One of China's main strategic goals since the second half of the twentieth century has been the creation of a superpower with an efficient economy that holds the leading position in the world and the realization of the traditional Chinese maxim: "a strong nation is a rich nation." The modernization of China's economy has been inextricably linked to the development of its own innovation system, as a challenge to foreign economic globalization.

The ideological basis on the path of Chinese reform was the theory of technological progress of Deng Xiaoping. It identified the importance of innovation policy in economic development. It was based on economic reform, one of the most important elements of which was the new strategy, called "Openness Policy".

The result of the reforms was the formation of a new type of real investment, when private business interests were counterbalanced by government investment. A new economic institute was formed a technology market designed to facilitate the transfer of innovative achievements from creators to consumers.

China has continually transformed the elements of its innovation strategy and refined them in the global direction of innovation. The result of public policy was the formation of one of the largest national innovation systems (NIS) in the world. To date, China's NIS is a complex set of public and private institutions that are closely interconnected. Their joint activity is aimed at creating, using and improving new and high technologies.

The modern NIS of China is contained in its own features of the administrative-command part and the market system, elements that are formed under the current trends that exist only in the economy, are used for all, international innovation services.

China's experience is inevitable for countries where innovation policy is just emerging and the contours of the future NIS have not yet been identified, for countries facing the challenge of modernizing the national economy and integrating more effectively into the world economy. and a competitive economy. China's GDP of 147 billion USD. In 1978, it increased to 642 billion USD in 2010. China is the world leader in FDI. Their total volume for the period 1979-2009 is 943 billion USD. By value of its gold and currency reserves in 2011, the country took the first place in the world 3.44 trillion USD. In 2010, the People's Republic of China became the world leader in manufacturing in manufacturing. In 2010, China came in first place in the world in terms of production of electronic information products. Such impressive achievements are largely explained by the thoughtful and balanced structural policy of the Chinese leadership adapted to the conditions of 
globalization and informatization. Structural transformations of the industry have become a key link in China's economic reforms. Traditional industries, where most of the manufacturing industry is created and mainly concentrated in the workforce, are being rapidly upgraded and translated into automated technologies, leaping to increase efficiency and competitiveness. Gradually, the economy is translated into a resource-saving means of production. It is most clearly manifested in high-tech industries. The state stimulates structural changes and helps to solve social problems arising from such transformations. The state environmental policy is being improved, its fundamental principles are changing.

Since 1978, when the International Patent Cooperation Treaty came into force, the United States has outpaced all countries in terms of innovation annually. However, over the past 20 years, the number of Chinese patents has increased 200 times. The main patent applicants for the third consecutive year is Huawei, one of the largest manufacturers of telecommunications equipment.

"China's stepping up to the number of international patent applications filed by the World Intellectual Property Organization (WIPO) is one of the manifestations of a long-term shift in the innovation trajectory toward the East: today, more than half of all applications are from Asia," WIPO Francis Harry.

Therefore, the development of innovation in China through macroeconomic regulatory levers is a relevant research topic.

\section{Problem Formulation}

The purpose of the article is to investigate the current state of China's national innovation system and to analyze the experience of the country's national innovation strategy. It is necessary to determine the predictive values of the main factors of innovative development of the Chinese economy.

\section{Problem Solution}

China is moving rapidly into the technological future. This has a significant impact including the average wage in the country [1].

Currently, about 600 cities in China are using "smart construction". Following the continuous development and improvement of Big Data, Internet of Things and Artificial Intelligence technologies, a new wave of smart cities is being built [2].

Ukraine's innovation potential remains objectively high, especially given important indicators such as the generation of new ideas and new technologies $[3,-5]$. Many experts from Ukraine work in world research centers, and this is an eloquent argument. In order not to lose the chance to remain an innovative state, Ukraine needs to build strong partnerships with China, a country moving forward and offering its support in the path of innovative development [6].

At the present stage, China's economy is transforming towards improving the quality and efficiency of growth, conducting further modernization and enhancing the contribution of the national innovation system to the country's economic development. These lines of economic strategy formed the basis for the 12th Five-Year Plan, which was formally adopted at the 17th session of the National People's Congress in March 2011 [7].

Despite a slight slowdown in China's GDP during the $12^{\text {th }}$ Five Year Plan, China has achieved remarkable results in the economy, the social sphere and science. In 2015, the GDP growth rate of China amounted to $6.9 \%$ and it ranked 1 st in the world [8]. The growth of the Chinese economy in 2016 was $6.5-7 \%$, and the average of the showable ones in the period of 2020 is at least $6.5 \%$.

According to the World Bank, China accounts for $21 \%$ of all high-tech exports in the world. In terms of the use of "green technology", the PRC came in first place in the world. To organize modern high-tech industries in the country created its "Silicon Valley", there are 53 zones of knowledgeintensive industries and more than 70 scientific and technical zones for professionals who have received education abroad. The country considers software as the most promising areas of scientific and innovation activity, creation of information security systems, formation of large integration networks [9].

At this stage, China's creation of Special Economic Zones (SEZs) is an effective institutional support system for China's innovation activities. Such zones provide for preferential investment conditions, which have led to large-scale FDI attraction and, in turn, the emergence of advanced technologies. Today, the level of informatization in the eastern regions of China, thanks to the functioning of the FEZ, is in line with Japan's indicators and is approaching that of the USA [10].

For the United States, China is an important trading partner and the largest buyer and holder of US sovereign debt bonds to date. The responsible behavior of the political and financial authorities of the PRC today largely depends on the dynamics of 
the yield of US debt securities. And so the stability of the financial position of the US federal government. And the dynamics of US domestic investment in recent years has become significantly dependent on the degree of aggression of investment activity in United States companies, directly or indirectly related to Chinese capital $[11,12]$

In this regard, the PRC and the US are growing in their willingness to mutually discuss their positions on such issues as liberalization of the international trade and investment regime, regulation of high technology exports, protection of interests of investors and owners in foreign jurisdictions, protection of intellectual property rights [13].

The two countries are united by the lack of interest in destabilizing the military and political situation in the CBA, including in the first place on the Korean Peninsula.

In addition, the United States and China have common interests in so-called "unconventional" threats and security challenges stemming from organized crime communities active in cybercrime, international fraud, drug trafficking, etc.; natural and man-made disasters, negative climate change. It is noteworthy that all these issues in recent years have become part of the intergovernmental contacts, including at the highest level [14]. The limits of a possible improvement in relations between the two countries determine their rivalry for influence in the region and American public opinion, which regards the PRC as a state ideologically alien and politically unfriendly to the United States.

The main areas of conflict of interest will be military and, first of all, naval construction in China, the opacity of its military potential, territorial disputes and conflicts in the South China and East China Seas, as well as the excessive role of the Chinese state in the economy and foreign trade, according to the United States activities [15].

The PRC, for its part, will feel growing concern about the so-called "repositioning" of the US in Pacific Asia and increasing their military presence in the region. China also has great concerns about US plans to create a global missile defense system.

In addition, the PRC does not want to increase US influence on the processes of economic integration in the APR and seeks to promote those formats that exclude or limit the role of the United States [16].

Today, China is leading the world in such scientific fields as chemistry, materials science and physics. A number of important scientific and technological breakthroughs have been achieved in areas such as quantum communications, manned space flight, the moon program, the Beidou navigation system and others. In recent years, the Chinese government, focused on market demand, has continuously encouraged enterprises to innovate. A number of scientific and technological giants are growing rapidly, such as Alibaba, Huawei, Tencent and others, which allow the country to occupy the first position in the world in the following fields: artificial intelligence, $5 \mathrm{G}$, mobile payments, high-speed rail, cars on new energy sources, financial technologies. At the same time, every effort is made in the country to protect intellectual property rights, improve the mechanism for education and training of scientific and technical personnel, and every year the amount of funding for scientific research is increased [17].

For a detailed examination of the state of development of innovative processes for each country, we analyze the indicators determined by the official Internet resource of statistics UNCTADstad [18]. They are indicative of the innovative and technical state of the countries studied, namely: $x_{1}$ - GDP (million USD); $x_{2}$ balance of payments, current account less annual (million USD); $x_{3}$ - foreign direct investment: Inward and outward flows and stock, annual (million USD).

In order to accurately reflect the integration processes that are objectively present in the international economy, it is necessary to identify significant relationships and quantify them. This approach requires the disclosure of causation. Causality refers to such a relationship between processes when changing one of them is the consequence of changing the other. This problem can be solved by regression analysis. With regard to this analysis, it should be noted that not all factors affecting economic processes are random variables, so the analysis of economic phenomena usually considers the relationship between random and nonrandom variables. Such relationships are called regression, and the method of mathematical statistics they study is called regression analysis [19].

To predict the development of integration processes we find equations of growth curves of the following studied indicators, which are reasonable indicators of innovative development of countries in the conditions of globalization: $x_{1}$ - GDP; $x_{2}$ - balance of payments, current account (annual); $x_{3}$ - foreign direct investment (annual); (Table 4). 
Table 1. Foreign direct investment: Inward and outward flows and stock, annual (million USD)

\begin{tabular}{|l|r|r|r|r|r|r|r|r|}
\hline Country & $\mathbf{2 0 0 9}$ & $\mathbf{2 0 1 3}$ & $\mathbf{2 0 1 4}$ & $\mathbf{2 0 1 5}$ & $\mathbf{2 0 1 6}$ & $\mathbf{2 0 1 7}$ & $\mathbf{2 0 1 8}$ & $\mathbf{2 0 1 9}$ \\
\hline Ukraine & 1715 & 10913 & 4816 & 6495 & 7207 & 8401 & 4499 & 410 \\
\hline China & 60630 & 108312 & 95000 & 114734 & 123985 & 121080 & 123911 & 128500 \\
\hline USA & 53146 & 215952 & 306366 & 143604 & 198049 & 229862 & 169680 & 230768 \\
\hline Egypt & 2157,4 & 9494,6 & 6711,6 & 6385,6 & -483 & 6031 & 4192,1 & 4783,2 \\
\hline France & $-2573,58$ & 37594,75 & 30733,24 & 13889,23 & 31641,9 & 16978,83 & 42892,29 & 15191,12 \\
\hline Poland & 12440,02 & 13862,43 & 11888,5 & 12795,67 & 18258,47 & 7119,581 & 119,5968 & 13882,85 \\
\hline Hungary & 4265,732 & 6327,186 & 1995,316 & 2192,811 & 6300,122 & 14374,98 & 3097,26 & 4039,38 \\
\hline Greece & $-10192,9$ & 8126,854 & 23805,19 & 65642,45 & 67514,65 & 20316,23 & 18192,71 & 1830,892 \\
\hline Italy & 20125,86 & $-10835,3$ & 20076,6 & 9178,261 & 34323,8 & 92,51003 & 25004,36 & 11450,82 \\
\hline Turkey & 2785 & 19851 & 8585 & 9086 & 16136 & 13283 & 12357 & 12146 \\
\hline Belarus & 163,8 & 2187,9 & 1876,5 & 1393,4 & 4002,4 & 1429,3 & 2229,6 & 1798,2 \\
\hline $\begin{array}{l}\text { Russian } \\
\text { Federation }\end{array}$ & 15444,37 & 74782,91 & 36583,1 & 43167,77 & 55083,63 & 50587,56 & 69218,9 & 20957,66 \\
\hline
\end{tabular}

Table 2. Gross domestic product: Total, current and constant (million USD)

\begin{tabular}{|l|l|l|l|l|l|l|l|}
\hline Country & \multicolumn{1}{|c|}{$\mathbf{2 0 1 3}$} & \multicolumn{1}{|c|}{$\mathbf{2 0 1 4}$} & \multicolumn{1}{|c|}{$\mathbf{2 0 1 5}$} & \multicolumn{1}{|c|}{$\mathbf{2 0 1 7}$} & \multicolumn{1}{|c|}{$\mathbf{2 0 1 8}$} & \multicolumn{1}{|c|}{$\mathbf{2 0 1 9}$} \\
\hline Ukraine & 188110 & 121552 & 141209 & 169334 & 182592 & 188350 & 135472 \\
\hline China & 4547276,65 & 5105457,84 & 5949785,24 & 7314444,46 & 8229447,25 & 9181203,79 & 10066674,2 \\
\hline USA & 14814975,6 & 14517121,3 & 15064731,7 & 15619010,7 & 16266284,8 & 16873199 & 17526950,9 \\
\hline Egypt & 164843,994 & 187977,632 & 214629,714 & 231100,308 & 260149,063 & 255198,99 & 282344,856 \\
\hline France & 2930050,71 & 2699121,76 & 2652198,26 & 2868755,31 & 2692482,83 & 2812991 & 2848702,92 \\
\hline Poland & 530175,954 & 436470,566 & 476687,892 & 524354,309 & 496199,701 & 525863,202 & 547262,066 \\
\hline Hungary & 156578,898 & 129359,842 & 129583,005 & 139439,621 & 126824,84 & 133423,899 & 137109,913 \\
\hline Greece & 3747055,45 & 3412770,25 & 3412008,77 & 3752109,94 & 3533242,46 & 3730260,57 & 3852273,18 \\
\hline Italy & 2391963,51 & 2186107,54 & 2126620,4 & 2278230,39 & 2091760,74 & 2149484,52 & 2156577,27 \\
\hline Turkey & 730325,317 & 614569,871 & 731144,392 & 774775,177 & 788862,893 & 822148,918 & 800997,883 \\
\hline Belarus & 60752,1648 & 49208,6499 & 55220,9491 & 59734,6026 & 63615,4426 & 71709,5137 & 76126,9113 \\
\hline $\begin{array}{l}\text { Russian } \\
\text { Federation }\end{array}$ & 1660848,06 & 1222645,89 & 1524916,7 & 1904791,25 & 2017468,16 & 2096774,22 & 1865327,67 \\
\hline
\end{tabular}

Table 3. Balance of payments, Current account net, annual (million USD)

\begin{tabular}{|l|l|l|l|l|l|l|l|}
\hline Country & \multicolumn{1}{|c|}{$\mathbf{2 0 1 3}$} & \multicolumn{1}{|c|}{$\mathbf{2 0 1 4}$} & $\mathbf{2 0 1 5}$ & $\mathbf{2 0 1 6}$ & \multicolumn{1}{|c|}{$\mathbf{2 0 1 7}$} & \multicolumn{1}{|c|}{$\mathbf{2 0 1 8}$} & \multicolumn{1}{|c|}{$\mathbf{2 0 1 9}$} \\
\hline Ukraine & 148734 & 188110 & 121552 & 141209 & 169334 & 182592 & 188350 \\
\hline China & 3504410,56 & 4547276,65 & 5105457,84 & 5949785,24 & 7314444,46 & 8229447,25 & 9181203,79 \\
\hline USA & 14571269,3 & 14814975,6 & 14517121,3 & 15064731,7 & 15619010,7 & 16266284,8 & 16873199 \\
\hline Egypt & 132165,347 & 164843,994 & 187977,632 & 214629,714 & 231100,308 & 260149,063 & 255198,99 \\
\hline France & 2668843,92 & 2930050,71 & 2699121,76 & 2652198,26 & 2868755,31 & 2692482,83 & 2812991 \\
\hline Poland & 428755,216 & 530175,954 & 436470,566 & 476687,892 & 524354,309 & 496199,701 & 525863,202 \\
\hline Hungary & 138580,12 & 156578,898 & 129359,842 & 129583,005 & 139439,621 & 126824,84 & 133423,899 \\
\hline Greece & 3435506,66 & 3747055,45 & 3412770,25 & 3412008,77 & 3752109,94 & 3533242,46 & 3730260,57 \\
\hline Italy & 2203972,56 & 2391963,51 & 2186107,54 & 2126620,4 & 2278230,39 & 2091760,74 & 2149484,52 \\
\hline Turkey & 647139,782 & 730325,317 & 614569,871 & 731144,392 & 774775,177 & 788862,893 & 822148,918 \\
\hline Belarus & 45275,7388 & 60752,1648 & 49208,6499 & 55220,9491 & 59734,6026 & 63615,4426 & 71709,5137 \\
\hline $\begin{array}{l}\text { Russian } \\
\text { Federation }\end{array}$ & 1299703,46 & 1660848,06 & 1222645,89 & 1524916,7 & 1904791,25 & 2017468,16 & 2096774,22 \\
\hline
\end{tabular}


Table 4. Equation of growth curves of the studied indicators and value of their statistical criteria

\begin{tabular}{|c|c|c|c|c|}
\hline Country & Equation of growth curves & $\begin{array}{c}\text { Coef. of } \\
\text { Determination }\left(R^{2}\right)\end{array}$ & \begin{tabular}{|c|} 
Fisher`s \\
Transformation \\
$(F)$
\end{tabular} & $\begin{array}{c}\text { Durbin-Watson } \\
\text { statistic }(D W)\end{array}$ \\
\hline \multicolumn{5}{|c|}{ Gross Domestic Product $\left(x_{1}\right)$} \\
\hline Ukraine & $9750,44+174,898 \cdot t^{2}$ & 94,486 & 308,45 & 0,87 \\
\hline China & $\left(873,428+5,99249 \cdot t^{2}\right) \cdot t^{2}$ & 99,392 & 2941,39 & 0,594 \\
\hline United States & $58700,1+551,618 \cdot t^{2}$ & 93,152 & 244,84 & 0,322 \\
\hline Egypt & $\operatorname{sqrt}(7,2653 \cdot 1011+3,96 \cdot 1011 \cdot t)$ & 84,079 & 95,06 & 0,5949 \\
\hline France & $\operatorname{sqrt}\left(4,751 \cdot 1012+2,8 \cdot 1010 \cdot t^{2}\right)$ & 83,885 & 93,70 & 0,748 \\
\hline Poland & $\exp (10,0359+0,43159 \cdot \operatorname{sqrt}(t))$ & 85,669 & 107,60 & 0,409 \\
\hline Hungary & $(1021+26,8764 \cdot t) \cdot t^{2}$ & 81,059 & 77,03 & 0,466 \\
\hline Greece & $\exp (11,6911+0,0831001 \cdot t)$ & 93,8329 & 273,87 & 0,5905 \\
\hline Belarus & $213149+5114,95 \cdot t^{2}$ & 91,6941 & 198,71 & 1,0322 \\
\hline Turkey & $\operatorname{sqrt}\left(2,039 \cdot 1010+1,8 \cdot 109 \cdot t^{2}\right)$ & 93,1693 & 245,52 & 1,1353 \\
\hline Italy & $\left(3057,64+3,24027 \cdot t^{2}\right) \cdot t^{2}$ & 89,4379 & 152,42 & 0,1457 \\
\hline $\begin{array}{l}\text { Russian } \\
\text { Federation }\end{array}$ & $\left(204,356+0,648858 \cdot t^{2}\right) \cdot t^{2}$ & 78,7584 & 66,74 & 0,7217 \\
\hline \multicolumn{5}{|c|}{ Balance of Payments, Current Accounts (Annual) $\left(x_{2}\right)$} \\
\hline Ukraine & $21,9786-16,7895 \cdot t^{2}$ & 62,4784 & 29,97 & 1,4926 \\
\hline China & $1 /(-0,0000494+0,00058 / t)$ & 88,7342 & 141,78 & 1,08652 \\
\hline United States & $1017,18-15,5759 \cdot t^{2}$ & 41,6212 & 12,83 & 0,47287 \\
\hline Egypt & $28902,3-195,504 \cdot t^{2}$ & 85,2051 & 103,66 & 1,02186 \\
\hline France & $-83883+18584,2 \cdot t$ & 91,379 & 190,79 & 0,652995 \\
\hline Poland & $-5930,79+19,1974 \cdot t^{2}$ & 27,4915 & 6,82 & 0,400061 \\
\hline Hungary & $42225,3-26011,1 \cdot \ln (t)$ & 32,8728 & 8,81 & 0,523661 \\
\hline Greece & $2172,55-6985,18 \cdot \ln (t)$ & 35,1201 & 9,74 & 0,926636 \\
\hline Belarus & $-13926,3+29747,7 \cdot \ln (t)$ & 56,3935 & 23,28 & 1,28765 \\
\hline Turkey & $908,692-166,038 \cdot t^{2}$ & 78,3596 & 65,18 & 1,96595 \\
\hline Italy & $-83778,6-167751 \cdot \ln (t)$ & 44,7989 & 14,61 & 0,396942 \\
\hline $\begin{array}{l}\text { Russian } \\
\text { Federation }\end{array}$ & $2258,21-35,1579 \cdot t^{2}$ & 51,3989 & 19,04 & 1,27336 \\
\hline \multicolumn{5}{|c|}{ Foreign Direct Investment, Domestic and External Flows and Inventories (Annual) $\left(x_{3}\right)$} \\
\hline Ukraine & Belarus & Belarus & Belarus & Belarus \\
\hline China & China & China & China & China \\
\hline United States & $-2615,92+2034,77 \cdot \operatorname{sqrt}(t)$ & 31,6361 & 8,33 & 0,812339 \\
\hline Egypt & $24575,8+172,303 \cdot t$ & 0,490564 & 0,09 & 1,72315 \\
\hline France & $46409,1-35450,6 / t$ & 3,13081 & 0,58 & 1,84016 \\
\hline Poland & $\operatorname{sqrt}\left(1,159 \cdot 10^{7}+119162 \cdot t^{2}\right)$ & 11,6697 & 2,38 & 2,2026 \\
\hline Hungary & $1858,37+6405,96 \cdot \ln (t)$ & 14,0604 & 2,94 & 2,26756 \\
\hline Greece & $2172,55-6985,18 \cdot \ln (t)$ & 24,1231 & 5,72 & 1,34907 \\
\hline Belarus & $\exp (7,33781+0,201009 \cdot t)$ & 79,1912 & 68,50 & 0,71162 \\
\hline Turkey & $\exp (6,25619+0,195304 \cdot t)$ & 76,4066 & 58,29 & 0,807673 \\
\hline Italy & $1 /(0,0000051+0,000018 / t)$ & 52,7761 & 20,12 & 1,13479 \\
\hline $\begin{array}{l}\text { Russian } \\
\text { Federation }\end{array}$ & $1 /(0,0003679+0,003537 / t)$ & 60,9077 & 28,04 & 0,875935 \\
\hline
\end{tabular}

[authors' calculations] 
The analysis of statistical criteria in the form of coefficients of determination (R2), Fischer (F) and Darbin-Watson (DW) indicates the statistical reliability of the obtained models and enables them to be used to find the predicted indicators of development of international integration, whose behavior is described by the corresponding equations (growth curves).

On the basis of the calculated growth curves, the projected values of the indicators have been calculated, which comprehensively characterizes the level of trade and economic status of the main trading partners of Ukraine and the development of international integration of the studied countries that are members of integration associations.

The visualization of the calculated projected values of the indicators for each of the studied indicators in the perspective three-year period is presented in Fig. 1 (a-c).

\section{Conclusion}

Analysis of the predictive values of innovative development of China and other countries determine the trends of globalization processes. This is how we see GDP growth, especially for countries such as China and the US. The forecast showed a positive balance of payments only for Hungary, Russia and Greece, for other countries it is negative, the largest of which is in the USA. Leaders in foreign investment are countries such as China, the US and Russia, and Ukraine also has a slight but upward trend.

The success of economic and political reforms has formed the basis for the transition of the Middle Kingdom from a group of poor countries to a category of middle-income countries. Nowadays, in order to move towards rich economically developed countries, China has moved to the next stage of economic development - based on innovation and high technology. Implementing a comprehensive innovation strategy will require improving the efficiency of the national innovation system, creating the necessary innovation infrastructure, implementing a set of measures to reform the financial and banking system.

The study found that China's NIS became an important factor in the development of China's economy, science and technology, which enabled the country to become one of the world's major economic and scientific nations.
Thus, in recent times, expanding the scope of market mechanisms and stimulating innovation at the micro level, the Chinese leadership has not lost sight of the macroeconomic levers necessary to address strategic objectives. The state initiated the creation of zones of high technology, technology parks, innovation clusters, funds for support of innovative projects. As you can see, the integration of science and production took place in the process of formation of large corporations, which organizationally and economically combined powerful production and scientific and technical potential of a particular industry. Large industry corporations have become a key link in China's economic system.

China still remains the world leader in the number of patent applications filed with national patent agencies. Today, more applications are filed with the Patent Office of the People's Republic of China than in the United States and Japan patent organizations combined.

In researching the current state of China's innovation processes, the following trends can be identified:

- innovations taking place in the field of production, the basis for which is the maturity of supply chains. The leadership of Chinese enterprises focusing on research and development, the most representative of which is Huawei Technologies Co., Ltd., is particularly noticeable. Based on a conglomerate of electronics manufacturing in China, the development of next-generation products is happening more than ever;

is a mechanism for innovation, the main role of which belongs to the companies-creators of platforms that have emerged in the digital economy. Major Internet companies, most notably Baidu, Alibaba, and Tencent, have been deploying mobilebased services since the beginning of the mobile communications era. Thus, they create ecosystems of the digital economy, the core of which are the socalled "super-applications";

- innovations of social introduction: distribution of already mentioned "super-applications" and payments through mobile devices create conditions that allow to exclude a person from the process of payments. As a result, many brand new services are being born, such as mini-shops within walking distance of "combine without vendors", automatic bicycle sharing systems, automatic restaurants, automatic car parking, etc. Social innovation is a process whereby, in an area where there were simply no ready-made solutions, new technologies are being introduced into society through a trial. 


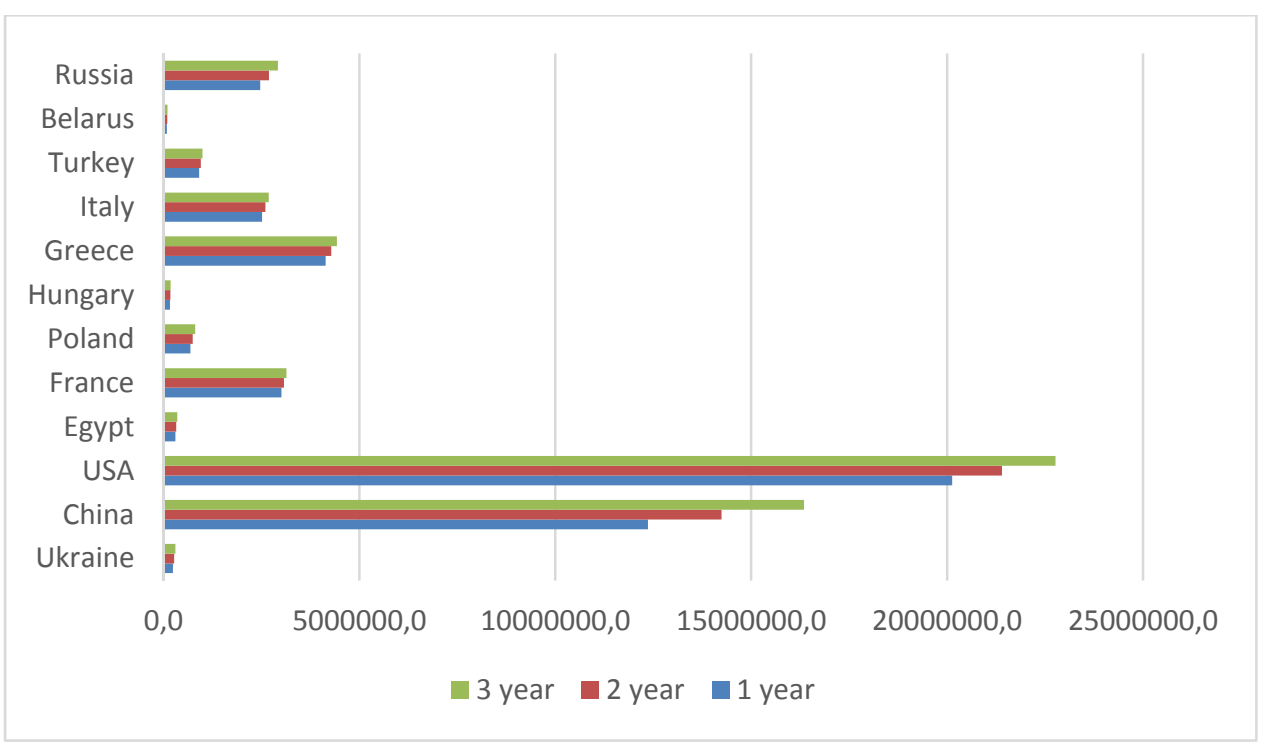

a) Gross domestic product, annual (mln. USD)

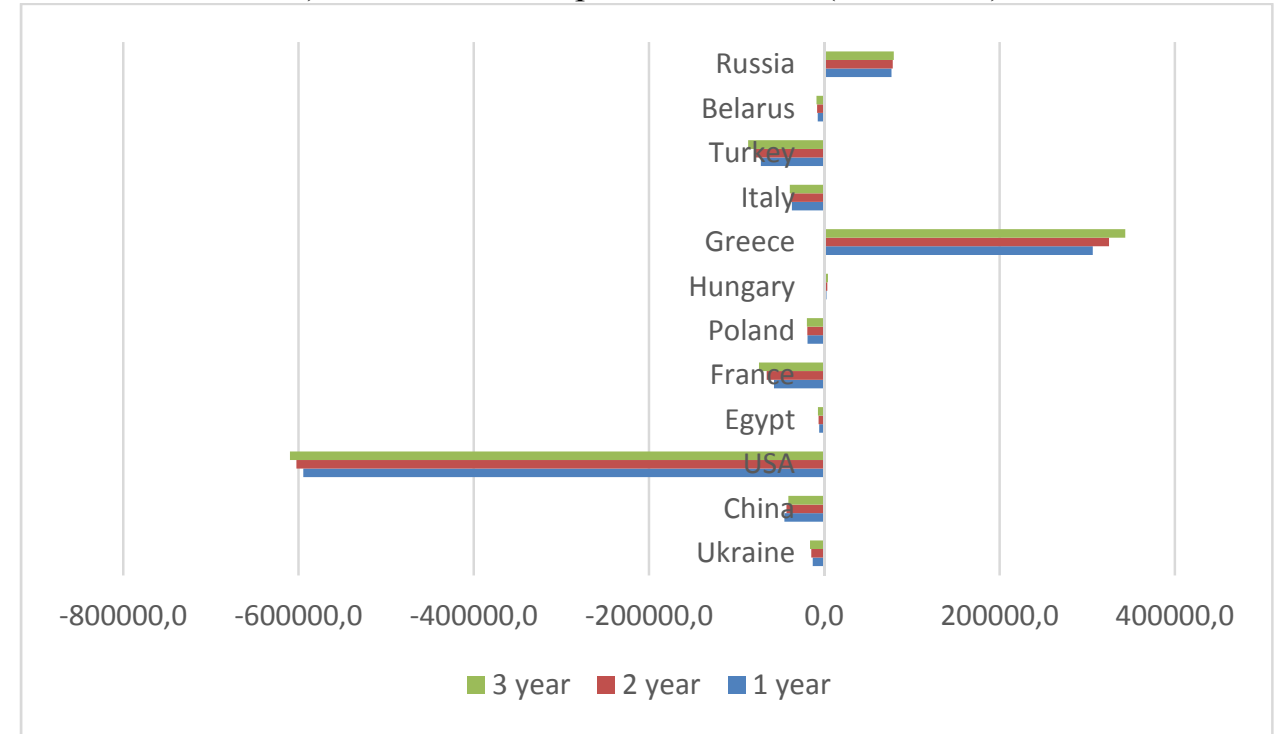

b) Balance of payments

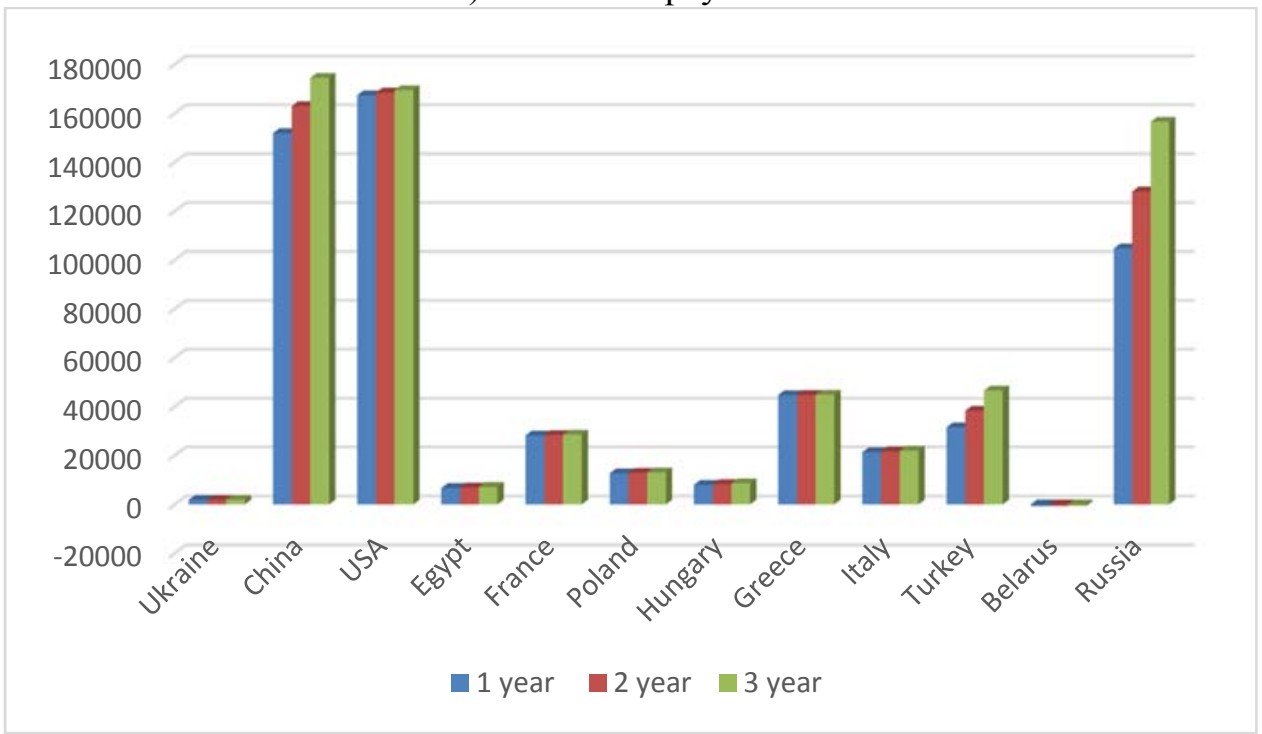

c) Foreign Direct Investment (mln. USD)

Fig. 1. Forecasting macroeconomic indicators of China and other countries in 2020-2022 [developed by the authors] 
The main distinguishing feature of Chinese and international approaches to innovation processes is the acceleration of product launch, coupled with low cost and large scale. This feature, among other things, helped the Chinese company Huawei to become third in the smartphone market, after Apple and Samsung. In addition, the application of accelerated innovation can be seen not only in online startups and the electronics sector, but also in more traditional business segments such as pharmaceuticals, telecommunications, information technology, manufacturing of medical and industrial equipment.

It is believed that the Chinese NIS is unstable, seeing the main drawback of the Chinese NIS model in its hybridity, namely, in the contradictory combination of public administration methods and instruments with the market mechanism. However, it is determined that the combination of heterogeneous elements in the Chinese NIS is realized through a successfully found symbiosis of state and market regulation of the economy, science, technology, innovation processes, which is a guarantee of long-term sustainability of the economy in the future. It is the state intervention that can compensate for the defects of the market, and the market, in turn, helps to overcome the shortcomings of state regulation through the development of competition.

Thus, China is building the world's most powerful economy based on innovation and knowledge. This development is not fundamentally suited to the current global leader - the United States. Therefore, in the future we should expect a further escalation of the race for global leadership between the two countries, which can take many different forms from sanctions and trade war to military conflict. It is this state of affairs that implies the redistribution of the world's wealth and spheres of influence, and the transfer in the future of a high-tech manufacturing core from the West to the East.

\section{References:}

[1] Mark J. Greeven, George S. Yip, and Wei Wei, Understanding China's Next Wave of Innovation, MIT Sloan Management Review, 2019. URL: https://sloanreview.mit.edu/article/ understanding-chinas-next-wave-of-innovation/

[2] https://www.capital.ua/ru/publication/124786kak-kitay-obkhodit-ssha-v-gonke-zaiskusstvennyy-intellekt
[3] http://magazine.faaf.org.ua/innovaciynadiyalnist-v-umovah-ekonomichnoikonkurencii.html

[4] Babenko, V., Perevozova, I., Kravchenko, M., Krutko, M., \& Babenko, D. Modern processes of regional economic integration of Ukraine in the context of sustainable development. E3S Web of Conferences, Vol.166, No.12001, 2020. https://doi.org/10.1051/e3sconf/202016612001

[5] http://chinanew.tech/china innovation 2017

[6] https://rb.ru/list/10-chinese-startups-2018/

[7] http://aucc.org.ua/innovatsiyniy-kitay-vidinformatsiynih-tehnologiy-do-data-tehnologiy

[8] Babenko, V., Formalization of the Model of Management of the Technological Innovations, CEUR Workshop Proceedings, Vol.2393, 2019, pp. 595-602. Online, http://ceur-ws.org/Vol2393/. URL: http://ceur-ws.org/Vol2393/paper 431.pdf

[9] https://www.msn.com/enus/money/markets/28-incredible-made-inchina-innovations-that-are-changing-theworld/ss-BBRWnlD

[10] https://www.researchgate.net/publication/2543 34733 Innovation in China

[11] http://4pda.ru/2019/01/19/355541/

[12] http://russian.cri.cn/news/homeList/380/202004 08/449450.html

[13] https://unctadstat.unctad.org/EN/

[14] V., Babenko, Z., Kulczyk, I., Perevosova, O., Syniavska and O., Davydova, Factors of the development of international e-commerce under the conditions of globalization, SHS Web of Conferences, Vol.65, No.2019, pp. 10-16. doi:https://doi.org/10.1051/shsconf/201965040 $\underline{16}$

[15] https://chinapower.csis.org/china-innovationglobal-leader/

[16] https://www.thedrum.com/opinion/2019/11/14/ chinese-tech-companies-are-leading-the-newglobal-innovation-revolution

[17] https://hbr.org/2014/03/why-china-cantinnovate

[18] https://www.telegraph.co.uk/connect/betterbusiness/business-solutions/china-technologyinnovation/

[19] Ramazanov, S., Antoshkina, L., Babenko, V., \& Akhmedov, R., Integrated model of stochastic dynamics for control of a socioecological-oriented innovation economy. Periodicals of Engineering and Natural Sciences, Vol.7, No.2, 2019, pp. 763-773. doi: http://dx.doi.org/10.21533/pen.v7i2.557 